Research Article

\title{
STUDY ON HUMAN RIGHTS PRINCIPLES IN THE MEDINA CHARTER AND ITS IMPLEMENTATION IN INDONESIA
}

\author{
Muannif Ridwan, M. Hasbi Umar², Hermanto Harun² \\ ${ }^{1}$ Islamic University of Indragiri, Riau-Indonesia \\ 2Sulthan Thaha Saifuddin State Islamic University, Jambi-Indonesia
}

Article history:

Submission 06 July 2021

Revised 17 October 2021

Accepted 20 October 2021

*Corresponding author:

E-mail:

anifr@ymail.com

\begin{abstract}
The principles of Human Rights are the goals of Islamic shari'a or maqashid al-shari'ah (the philosophy of Islamic law) which has been formulated by al-Ghazali and perfected by as-Syatibi. These principles are summarized in al-dlaruriyah al-khamsah or also called alhuquq al-insaniyah fi al-Islam (human rights in Islam). This concept consists of five basic principles that must be maintained and respected by every individual; Hifzhu al-Din (respect for religious freedom), Hifzhu al-Mal (respect for property), Hifzhu al-Nafs wa al-'Irdl (respect for life, right to life and individual honor), Hifzhu al-'Aql (respect for freedom of thought), and Hifzhu al-Nasl (respect for keeping offspring).This research is examined using a juridical-normative and socio-legal and historical approach. The principles of human rights in the Medina Charter consist of: the principles of justice, equality, freedom of religion, piety, and commanding good and evil. Iimplementation of human rights values in The Medina Charter in Indonesia, the author summarizes it into three areas of life; religion, nation and state consisting of:the field of religious harmony, the field of law and constitution enforcement and the field of socio-political life and the development of the political system. Among the authors' findings, the Medina Charter contains ideas that have strong relevance to the developments and desires of today's world community, especially for Indonesia. The ideas in the Medina Constitution were also absorbed by the founding figures of the Indonesian nation, which can be seen in the Jakarta Charter which later gave birth to Pancasila. The contents of the Medina Charter and Pancasila have in common as a sentence of sawa' (meeting point) diversity or a noble agreement that is constructive, loves, and defends Indonesia, as well as the Medina Charter.
\end{abstract}

Keywords: Human rights, Medina charter, Indonesia. 


\section{Introduction}

Human Rights (HAM) has been the center of attention of the international community since the 17th century AD and until now. Human rights are still a hot issue and much discussed in the national and international arena. This issue has colored contemporary Islamic intellectual discourse. Various discussions and seminars were held to discuss and discourse on it. Among the agenda in question is how to formulate the relationship between human rights and Islam (George Clack, 1998: 3).

Universal Declaration of Human Rights (Universal Declaration of Human Rights) by the United Nations (UN) in 1948 describes the fundamental human rights that the government agreed to protect. Among them are aimed at abolishing slavery, arbitrary detention, freedom of expression, and to the social and cultural aspects. In its preamble it states: "Recognition of the full natural dignity of human beings and the equal and inalienable rights of all family members. Humanity is the basis of freedom and justice in the world (Dalizar Putra, 1995: 32).

With the UN declaration, many Muslim intellectuals then reviewed the theological foundations of the values of human rights and justice which they considered already existed in the Islamic world, so that there were a lot of theological studies of human rights and justice from the perspective of the Qur'an and hadith. The declaration of the Medina Charter by the Prophet Muhammad SAW. enough to be strong evidence of these human rights values by guaranteeing the life rights of non-Muslims at that time. The Qur'an itself has laid the foundations of human rights as well as truth and justice, long before the thought of these things emerged in the world community. This can be seen in the provisions contained in the Qur'an, the maintenance of life and the provision of means of life, for example in the surah al-Maidah verse 32;

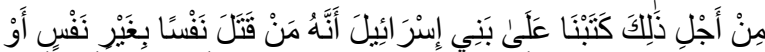

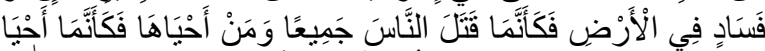

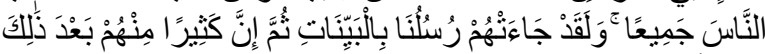

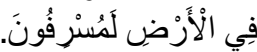

Meaning: Therefore We set (a law) for the Children of Israel, that: Whoever kills a human being, not because that person (kills) another person, or not because of causing mischief on earth, it is as if He had killed all mankind and Whoever preserves the life of a human, it is as if He has preserved the life of all mankind. And indeed Our Messengers have come to them with clear statements, then many of them after that really transgressed in doing mischief on earth.

While human rights in the books of authentic hadith, hasan and musnad-musnad, not only one form, including that of the Prophet SAW. said in the khutbah hajj wada': ....

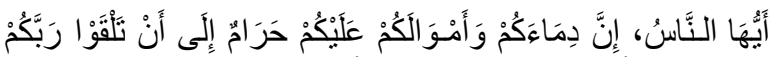

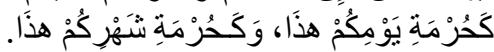

Meaning: "My brethren! Verily, your blood and your property are sacred to you, until your time comes before Allah like this holy day and month" (Sahih AlBukhari, No. 105 and Sahih Muslim, No. 1218).

Actually what the Prophet Muhammad saw. convey about the teachings of Islam that have covered all aspects of human life, from waking up until he wakes up from sleep. However, in some cases or problems, the information provided is still very universal. Precisely here, the Prophet. invites his people to use their minds so that they can compete in the face of change and development of the times.

So after the Prophet Muhammad saw. and the Muslims of Mecca emigrated to the city of Medina, the Prophet made an understanding or written agreement with the Muslims of Medina from the Muhajirin and Ansar with the Jews of Medina and their allies which became known as Shahifah al-Madinah or better known as the Medina Charter (Mitsaq al-Madinah) and The Constitution of Medina (The Constitution of Medina) which one of the contents of the agreement is concerned with the issue of equality in rights and obligations among the tribes in social, political and state life.

The Medina Charter is the first written constitution in the world which has laid the foundations for Human Rights based on Islamic Shari'ah. At the beginning of the preamble to 
the Medina Charter, it was stated that all humans are one people, born from the same source, so there is no difference between one person and another in everything. But in Islam there is one thing that makes a person considered higher in rank in the eyes of Allah, namely the level of faith, so it is not seen from skin color, ethnicity, race, country and gender, but a person's level of faith that distinguishes him from others (Zainal Abidin Ahmad, 2014).

The principles of human rights are the goals of Islamic shari'a or maqashid al-shari'a (the philosophy of Islamic law) which has been formulated by Imam Al-Ghazali and perfected by Abu Ishaq As-Syatibi. These principles are summarized in al-dlaruriyah al-khamsah (five basic principles) or also called al-huquq al-insaniyah fi al-Islam (human rights in Islam). This concept contains five basic principles that must be maintained and respected by every individual, namely; First, Hifzhu al-Din (respect for religious freedom); Second, Hifzhu al-Mal (respect for property); Third, Hifzhu al-Nafs wa al-'Irdl (respect for the soul, the right to life and individual honor); Fourth, Hifzhu al-'Aql (respect for freedom of thought) and; Fifth, Hifzhu alNasl (respect for keeping offspring) (Al-Ghazali, 2015: 34).

The principle of human rights referred to by the Medina Charter is equality between every human individual in all aspects of social life, as well as human freedom in religion and respect between religious adherents. Political rights are marked by the existence of equal rights between every human being before the law and socio-political. As for the protection of human rights (as well as politics), the state has four obligations. First, the state is obliged to protect civil rights through political products and legislation. Second, the state is prohibited from restricting, interfering or prohibiting the freedom of its citizens to carry out their personal and political activities. Third, the state through the police must take action when a crime occurs. Fourth, the state through the courts should carry out legal processes against those who commit crimes indiscriminately (Ian Shapiro, 2006: 80).

From the explanation above, it can be concluded that Islam has given great attention to human rights. This is reflected in the leadership of the Prophet. in fostering the Medina community to create a civil society (Qodri Azizy, 2004: 126-128). Therefore, the author's interest in the significance of this research focuses on the principles of human rights in the Medina Charter and the implementation of its values in Indonesia.

\section{Method}

This research is included in the category of library research. Literature study is reviewing data by exploring, observing, examining and identifying the existing knowledge in the literature to get a conclusion of truth, both philosophical and empirical. The main problems in this research will be examined using a juridical-normative approach and a socio-legal approach as well as a historical approach (Sulistyowati Irianto and Shidarta, 2009: 177-178).

The most primary source of data as the main basis for this research is the text of the Medina Charter which the author obtained from the book by Ibn Hisham entitled Al-Sirah al-Nabawiyyah, from the book at least the author can see the original text of the Medina Charter (Abu Muhammad Abdul Malik Ibn Hisham, 1329 H: 94-98). The secondary sources of this research are previous scientific research which discusses the Medina Charter without neglecting the sources from the Qur'an and Hadits as well as books that discuss the history of the Prophet Muhammad. While the tertiary sources include journals, magazines, internet or laws related to the theme of this research.

\section{Results and Discussion Principles of Human Rights in the Medina Charter}

The Medina Charter provides guidelines in the form of a set of ethical principles and values for the life of society and the state. The principles in question are universal in accordance with the transhistorical and eternal nature of Islam (Munawir Sjadzali, 1993: 233). The principles of human rights in the Medina Charter, in this study the author discusses them into 4 (four) principles; the principle of justice, the principle of equality, the principle of religious freedom and the principle of piety, amar 
makruf and nahi munkar. With these four principles-although there are several previous authors who have divided them into more than four principles-according to the author's opinion, the authors have included several other principles whose substance is related to human rights studies in the Medina Charter (Harun Nasution, 1985: 2).

\section{Principle of Justice}

The principle of justice is one of the most important principles in the life of society or the state. In fact, it may even be said that there is no basic principle so coveted throughout the history of mankind as the principle of justice. The principle of justice in its various dimensions is the highest ideal of mankind which is sometimes not easy to realize.

Islam commands its adherents to do justice or enforce justice in every action taken. In $\mathrm{Su}$ rah An-Nisa' verse 58:

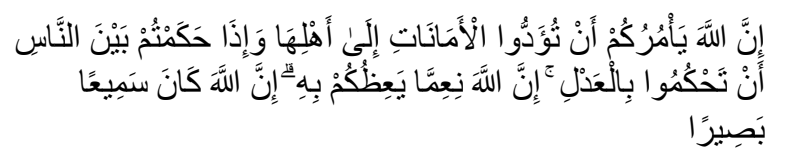

Meaning: Verily, Allah commands you to convey the message to those who are entitled to receive it, and (orders you) when setting the law between people so that you judge with justice. Verily, Allah has taught you the best. Verily Allah is All-Hearing, All-Seeing.

Justice is very important in the life of the nation and state. Charles E. Merriam put this justice as one of the principles in the goals of a country, namely external security, internal order, justice, public welfare and freedom.Afifa Rangkuti, Vol. VI, No. 1, 2017). It is the duty of the state administrators to create justice. The aim of the Indonesian state is to fulfill justice for all Indonesian people. This can be seen well in the Preamble to the 1945 Constitution, the state to be established is an Indonesian state that is just and aims to create social justice.

Principle justice in the Medina Charter which is expressly stated as a system of legislation in the life of the people of the Medina state. In Articles 2-10 it is stated that believers must be fair in paying diyat and redeeming captives. No party should be harmed. The essence of the provisions of these articles is so that hostilities and grudges do not continue between the disputing parties, so that their social relations and friendship remain harmonious. This can only be realized if all parties feel there is justice. Then Article 13 demands that believers be fair in opposing perpetrators of crime, injustice and sin even against their own children. This is because a believer who allows or covers up his child or close person who commits a sinful act is a reflection of an unfair attitude.

Likewise, if the believers enter into a peace agreement, it must be on the basis of equality and justice between them (Article 17 of the Medina Charter). If someone kills an innocent believer with sufficient evidence, then he must be punished for his actions (Article 21 of the Medina Charter). Fair treatment is also given to citizens of the non-Muslim group, the Jews by receiving protection and equality as obtained by the Muslims (Article 16 of the Medina Charter).

The provisions of the Medina Charter can be understood that the principle of justice is one of the legal systems of the Medina state. All citizens, both Muslims and non-Muslims, are treated fairly by obtaining protection rights and equal rights in social and political life. That is, as fellow human beings have the same right to get justice. Justice is not the right of one group only, but the right of every person. He is also the social pillar of the Medina community which demands that every citizen be fair in solving every problem, such as paying diyat and redeeming prisoners and upholding the law fairly. According to J. Suyuthi Pulungan, opposing the perpetrators of crime is also an effort to uphold justice. Because criminals always act unfairly and arbitrarily to achieve their goals.

\section{Equation Principle}

The equation (Al-musawah) by some scholars is understood as a logical consequence of the principles of al-syura and al-'adalah. One of the arguments of the Qur'an that is often used in this context is Surah al-Hujurat verse 13:

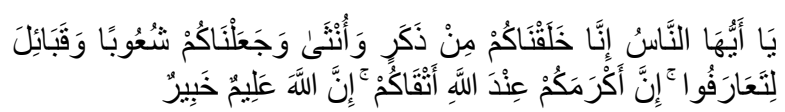


Meaning: 0 mankind, indeed We created you from a male and a female and made you into nations and tribes so that you may know one another. Verily, the most honorable of you in the sight of Allah is the one who is most pious among you. Verily Allah is AllKnowing, All-Knowing.

This principle, according to M. Ainul Fikri, sociologically dismantles the views of feudalism, whether religious feudalism, capitalist feudalism or aristocratic feudalism. How many kinds of social divisions should fall in the face of this concept. Because since its inception in the Arabian Peninsula, Islam has pioneered the concept of al-musawah when in other parts of the world there is still discrimination of ethnicity, class, wealth, position and even skin color.M. Ainul Fikri, 2015).

In the Medina Charter, provisions regarding the principle of equality are contained in Articles 16 and 46:

و إنه من تبعنا من يهود فإن له النصر والاسوة غير مظلومين ولا

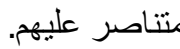

Meaning: And that the Jews who follow us will have the right of protection and equal rights without any persecution and no one to help their enemies.

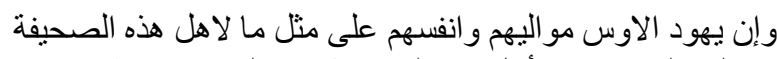

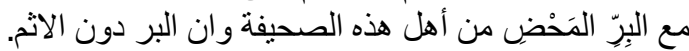
Meaning: The Jews of Al-'Aus, their allies and themselves have rights and obligations like other groups supporting this charter, with good and full treatment from all supporters of this charter. Verily, good (loyalty) is different from evil (treason).

According to J. Suyuthi Pulungan, this stipulation relates to the public benefit which guarantees their special rights as well as the rights and obligations of the Muslims. This is because the principle of equality in Islam is the recognition of equal rights between Muslims and nonMuslims. These stipulations are not only general in nature but also specific in nature, namely equality of rights to life, rights of life security, rights of protection for both men and women, and for both Muslim and non-Islamic groups (J. Suyuthi Pulungan, 1996: 151).

The similarities of the humanitarian element can be seen in the decree which states that all the inhabitants of Medina are one people or people who have the same status in social life (Articles 25-35); the right to self-defense (Article 36); equality of responsibility in maintaining the security of the city of Medina (Article 44); equality of obligations in carrying war expenditures when necessary (Article 24 and Article 38); equal rights in providing advice and advice for the good (Article 37); and equal rights to freedom of choice of religion and belief (Article 25-35), as well as the right to regulate each other's economic life (Article 38). These rightsThese are basic human rights that cannot be violated by anyone. Recognition of these rights also means recognition of the equality of all groups.

Thus it can be understood that The Medina Charter does not recognize the term dichotomy between humans. Islamic groups and other residents are equally recognized for their civil rights, no one group is privileged. The principle of human equality is also reinforced by the words of the Prophet Muhammad SAW:

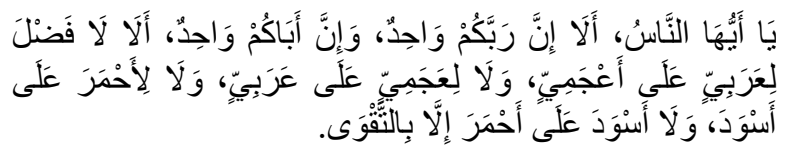

Meaning: O people, remember that your Lord is one and your father is one. Remember that there is no superiority of Arabs over Arabs, no superiority of non-Arabs over Arabs, black people or people of color, people of color over black people, except because of piety. (Ahmad bin Hanbal, Volume V, p. 411).

From the explanation above, it can be concluded that the implementation of the principle of equality in the perspective of the Medina Charter is essentially aimed at ensuring that every person or group finds their human dignity and can develop their potential fairly and properly. The principle of equality will also lead to the nature of mutual help and attitudes of social care between others, as well as social solidarity in a broad social scope. Prophet SAW. 
actualize this principle with the aim of eliminating the roots of jahiliyah fanaticism which prides itself on descent and race. With these similarities they can cooperate in the life of the state and society, even though between them there are differences in principles, namely differences in religion and creed.

\section{Principles of Religious Freedom}

In essence, the principle of religious freedom in The Medina Charter is to provide the widest possible guarantee and freedom for religious adherents to carry out the teachings of their respective religions. This is proven in $\mathrm{Ar}-$ ticle 25 . Although in that article only the children of Auf are mentioned, this also applies to all Jewish groups, because in the next chapter it is stated that the other Jews are the same as the children of Auf.

In Article 25 it is also stated that the Jews are one people with the believers. The later mention implies that the Jews are a parallel community with the community of believers. In this common life, the Jewish community is free to practice their religion. Islam does show a tolerant attitude towards other religions (Ahmad Sukardja, 2014: 167). Freedom of religion is in line with the word of Allah SWT. in the Surah alBaqarah verse 256:

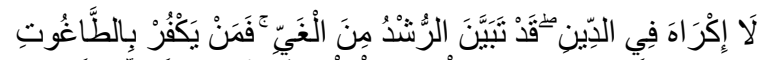

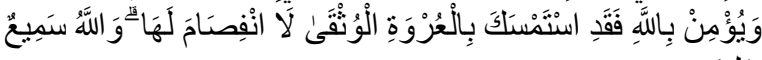

Meaning: There is no compulsion to (enter) religion (Islam); Indeed, the right path has become clearer than the erroneous path. Therefore, whoever disbelieves in Thaghut and believes in $\mathrm{Al}$ lah, then indeed he has clung to a very strong knot that will not break. And Allah is All-Hearing, All-Knowing.

This verse was revealed at the same time as the expulsion of the Banu Nadir Jews, a people who were expelled from Medina after the Banu Qainuqa'. The Medina Charter was established before the expulsion (Al-Wahidi, 1984: 76-77).

Thus, the principle of religious freedom contained in the Medina charter has a strong footing in the Qur'an, Medina is increasingly confirmed as one of the centers of civilization which among its characteristics provides a place for pluralism and knit it together in unity to maintain common interests. Every human being basically has the nature to live a just, pluralistic and civilized life. Therefore, a consensus is needed which is outlined in the form of a constitution that guarantees the freedom of each individual to embrace their respective beliefs without discrimination and intimidation (Zuhari Misrawi, 2009: 317). In Article 24, Article 37 and Article 38 it is stated that the joint obligation of religious groups is stated in the article that the Muslim and Jewish groups both bear the costs of fighting against those who attacked Medina.

\section{The Principle of Faithfulness, Amar Makruf and Nahi Munkar}

Principle ketaqwaan, amar makruf and nahi munkar stipulated in the Medina Charter is understood as the protection of human rights for the people of Medina related to the principle of vertical relations and horizontal relations of society. This principle is understood and formulated from its provisions in Article 13 which states:

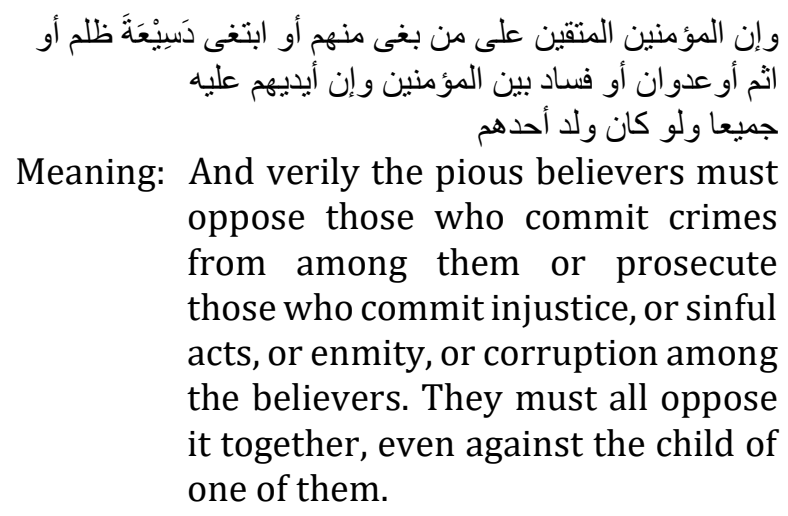

The principle of this determination, according to J. Suyuthi Pulungan, emphasizes the good and harmonious relationship of believers with Allah SWT. and the environment. The relationship of believers with Khaliq as a manifestation of their piety is reflected in carrying out all His commands and avoiding all His prohibitions. For this purpose, believers who are pious in their attitudes and actions must "guide by the best and most straight guidance". This means that it is guided by the instructions of Allah's revelation, the revelation received by the Prophet SAW. which came to be 
known as the Qur'an. The Qur'an is a book that there is no doubt in it as a guide for the pious, enlightenment for all mankind, guidance and lessons for those who are pious (J. Suyuthi Pulungan, 1996: 260).

In the provisions of the Medina Charter, it is known that the piety of the believer contains two dimensions. First, the divine dimension, namely the human relationship with God to fear Him (hablum minallah/vertical). Second, the social dimension, namely enforcing amar makruf and nahi munkar for the sake of realizing social order (hablum minannas/ horizontal). The author borrows the term Zainudin, MZ., these two dimensions are often referred to as "personal piety and social piety" (Zainuddin MZ, 2008).

Therefore, the principles of piety, amar makruf and nahi munkar as the principle of the state of Medina according to the people in addition to being devoted to Allah SWT, must also have social care, both for the task of enjoining good and forbidding evil. This type of society and government is what Islam aspires to, namely a country where the people and government try to create a community of faith and piety and secure the interests of the government in achieving its goals.Mohamed S. Elwa, 1983: 103). The aim of the government is to realize the right to world welfare and prohibit what is forbidden. Thus society and government move on the path that is pleased with Allah SWT. In addition to the obligation to be pious, believers are also given the right and obligation to order or invite other believers to do good deeds and prevent them from evil and evil deeds. Regarding this, the Qur'an Surah Ali Imran verse 104 states:

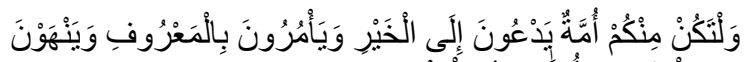

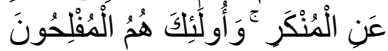

Meaning: And let there be among you a group of people who call to righteousness, enjoin the good and forbid what is evil; they are the lucky ones.

From the description above, it can be concluded that the urgency of this principle for the benefit of human life is important to implement in relation to government affairs and state life. So that the principles of piety, amar makruf and nahi munkar are used as one of the principles of the constitution or state legislation that is carried out consistently and effectively. With this principle, for people who judge that the government does not carry out the best interests of the state and the benefit of the people, and is contrary to the substance of Islamic principles, then they can give constructive criticism to the government and advise it, to follow other policies that are better, in accordance with the objectives. and the interests of the state or more in accordance with Islamic principles.

\section{Study on the Implementation of Human Rights Values in Indonesia}

The Field of Religious Harmony or Tolerance

The principle of religious harmony in the Medina Charter is to provide the widest possible guarantee and freedom for religious adherents to carry out the teachings of their respective religions. Islam's commitment to religious harmony (tolerance) and acknowledging the existence of plurality is stated firmly in article 25 of this Charter. This is as the author has also explained before.

In article 25 of the Medina Charter, it is also emphasized that the Jewish group is recognized as a unitary community with the Muslim group. This is proof that the Prophet SAW. very concerned about the attitude of high tolerance towards other groups. When Jews and people outside Islam commit injustice and crimes, then Muslims must take a firm stand against them.

Throughout the history of Islam, Rasulullah SAW. and the Muslims have never fought with people outside of Islam based on religious differences. Even if the war did occur, it would be solely because of political treason, as was the case with the polytheists of Medina. The Prophet's War. and Muslims and the polytheists of Quraish not because of their religious differences, but because of their hostility towards the Prophet and Muslims. General amnesty (forgiveness) granted by the Prophet SAW. to the people of Makkah after the events of Fathul Makkah (the liberation of the city of Makkah) by the Prophet Muhammad. and Muslims are proof that the Prophet SAW. fought against them not because of their polytheism but because of their hostility and betrayal (Ngudi Astuti, 2012: 270). 
Muslims, Jews and Christians each have the same freedom in worshiping and professing beliefs and preaching their respective religions. In this atmosphere of religious freedom, a religious dialogue or debate was held in Medina from these three major religions. The Jews completely rejected the teachings of Prophet Isa AS. and Prophet Muhammad SAW. They highlight that Uzair is the son of Allah. Meanwhile, from the Christian side, they put forward the understanding of the Trinity which recognizes Prophet Isa AS. as the son of God (Abu Bakr and Hurmain, 2016: 10). Meanwhile, the Prophet Muhammad SAW. invites all human beings to unite Allah SWT. To the Jews and Christians, the Prophet SAW. invites, "Let us accept the same sentence between us and you, that there is none we worship except Allah. We don't associate it with anything. There is no need for any of us to deify one another, apart from Allah." Look at the word of Allah SWT. In Surah Ali Imran verse 64:

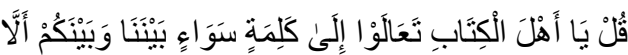

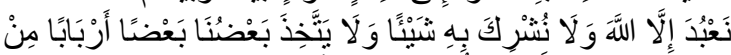

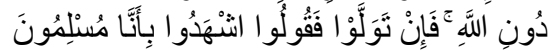

Meaning: Say: "O People of the Book, let (hold) to a sentence (decision) with which there is no dispute between us and you, that we worship not except Allah and we do not associate Him with anything and not (also) some of us make some others as gods besides Allah". If they turn away then say to them: "Witness, that we are the ones who surrender (to Allah)".

In the context of differences in religion/belief, the Indonesian people are united by the precepts of the One Godhead, legislation and law, which guarantees and gives freedom to the Indonesian people in embracing their religion. In terms of religion, Indonesia recognizes the existence and development of the six official state religions, namely Islam, Catholic Christianity, Protestant Christianity, Hinduism, Buddhism and Confucianism.

The Minister of Religion of the Republic of Indonesia in 1978-1984 (H. Alamsjah Ratu Perwiranegara) established the Tri Religious Harmony, namely three basic principles of regulation that can be used as the basis for tolerance between religious communities in Indonesia. The three basic principles referred to are as follows:

1) Internal harmony among religious people.

2) Inter-religious harmony.

3) Harmony between u religious matrimony with the government (Ministry of Religion of the Republic of Indonesia, 1982/1983: 13).

Regarding the rules regarding inter-religious harmony in Indonesia, in principle, it is no different from the rules in the Medina Charter. There is no fundamental difference and the two sources of the rules are about inter-religious harmony. Both of them give freedom to their respective religious adherents to practice their religion.

The principles contained in the Medina Charter, especially those related to the rules of inter-religious harmony, can be used as the basis for regulating the same problem in Indonesia. The attitude of the Prophet Muhammad SAW. in solving religious problems in Medina can also be used as a mirror to solve the problems of religious harmony that have emerged recently in Indonesia, especially since Indonesia has declared the realization of a civil society (Marzuki, 2016).

There are still many religious conflicts in Indonesia that require serious attention to take anticipatory steps for the peaceful life of religious people in the future. If it is not handled seriously, it is feared that more serious problems will arise in the context of nation and state development in the fields of politics, economy, security, culture and other fields. The change in the era like today should increase our public awareness of the importance of unity and integrity.

\section{The Field of Law and Its Relevance to Constitutional Enforcement}

Islamic history has recorded well the growth of civilized communities after the hijrah of the Prophet Muhammad SAW. to Medina. Together with all elements of the inhabitants of Medina the Prophet SAW. laying the foundations of civilization (madaniyyah) by making an agreement regarding religious, economic, social and political life. In this case, the bond of civilization is upheld by the universal 
spirit of divinity to lay down a just legal system and uphold human values (Abu Zahra, 1999:31).

According to Himas Muhammady Imammullah El Hakim in his thesis Principles of Constitutionalism in the Medina Charter and Its Relevance to the Indonesian Constitution, the Medina Charter as the world's first written constitution demonstrates the application of the principles of constitutionalism that can be learned as lessons for a modern state of law. The limitation of power which does not only apply democracy but even nomocracy is elaborated with bottom-up protection of people's rights. The strengthening of populist institutions through tribes and deliberation (syuro') is a hallmark of the application of the Medina Charter constitutionalism, especially in limiting government power. In addition, the protection of human rights is carried out communally through tribal institutions and constitutional agreements (Himas Muhammady Imammullah El Hakim, 2015).

As a state of law, Indonesia is based on the written constitution of the 1945 Constitution which contains the duties and authorities of state administrators, division of power in three state institutions (executive, legislative and judicial), and recognition and protection of human rights. The 1945 Constitution has a dynamic history in the application of the principles of constitutionalism. As a country that is also predominantly Muslim with a heterogeneous society, Indonesia can take lessons from the Medina Charter in the application of the principles of constitutionalism. As a social and political constitution, the Medina Charter has formal and substantial relevance to the Indonesian constitution. Institutional evaluation, strengthening of research institutions and massive constitutional education to the public are concrete forms of this relevance.

Meanwhile, according to Eko Priyono in his thesis entitled Principles of the rule of law in the Medina Charter and the Indonesian Constitution; In a comparative descriptive analysis at UM-Malang, the limitation of power is placed in a constitution which is the foundation of a country. The limitation of power includes the duties and authorities of state administrators as the bearers of the mandate in achieving common goals, and the recognition of human rights as areas that cannot be disturbed and must be fulfilled by the state. In other words, the authorities in carrying out their obligations are limited by the limits of their authority and basic areas (Eko Priyono, 2006).

In the context of Indonesia, if we read the history of the New Order's political journey, it is very much against the lines of the Indonesian Constitution. The New Order regime carried out hegemony and manipulation in all matters, including the law as a means of legitimizing its actions which in essence were not in accordance with the basis of the state. In addition, identity as a state of law is also tarnished and replaced by a state based on power. The rule of law means that in the administration of the state, the actions of its rulers must be based on law, with a view to limiting the power of the ruler and aiming to protect the interests of the people, namely the protection of the human rights of the people from arbitrary actions.

Basically the 1945 Constitution contains the principles of recognizing and protecting human rights, equality before the law, legality, Power Sharing, democracy, and impartial justice. The difference between the two is that there is no principle of power sharing in the Medina Charter. This can be understood because the fear of the arbitrariness of the ruler can be eroded by the nature of the Prophet Muhammad. as head of state as well as messenger of revelation. Therefore, this difference is not a deficiency in the Medina Charter. During the reign of Medina the Prophet Muhammad SAW. has exemplified how to be a good, responsible and fair leader of the country. Because of the Prophet SAW. aware that the law is the direction and limit of human behavior. So that when the law is obeyed, welfare and justice will be achieved by itself.

Although not exactly the same, Pancasila and the 1945 Constitution which have been agreed upon by the founding fathers are constitutions that resemble the Medina Charter, especially in the spirit of building equality, peace, and brotherhood despite different religious beliefs, groups in society and ethics. Because in essence the Medina Charter has become an excellent treasure for building a nation, on the 
one hand it also guarantees diversity among citizens (Zuhairi Misrwai, 2009: xvi).

We as Indonesians, Islamic law should no longer be something to be feared (to be applied) for a just and prosperous society, because this has been proven since the Medina Charter period where Islamic principles can guarantee the continuity of state administration. in a fair and equitable manner. However, to implement all of this, you do not have to apply Islamic criminal rules in Indonesia or even change the complete Unitary State of the Republic of Indonesia into an Islamic state (khilafah), the most important thing is that Islamic law must be able to animate and become the main foundation for the legal structure of Indonesia.

\section{Fields of Socio-Political Life and the} Development of Political Systems

Islam does not recommend its adherents to form a state, but Islam teaches how to form a society (society or ummah) in formulating an ideal and civilized society. The form of government and the Islamic political system is a secondary consequence of society. In civil society, the most fundamental thing that influences social change is the economic factor.Zainab $\mathrm{Al}$ Khudhairi, 1995: 119). This factor also influenced the birth of Islam in Arab society, even the political system that was born in Islam was only a reflection of the economic conditions at that time.Asghar Ali Engineer, 2009: 92).

The formation of a new Muslim society marked by the making of a written agreement (the Medina Charter) in $622 \mathrm{AD}$ was an initiative of the Prophet's efforts. to organize and unite his followers and other groups into an orderly and peaceful society. The provisions of the Medina Charter contain laws that regulate socio-political life with Muslims and non-Muslims who accept and acknowledge the Prophet SAW. as their leader.

The relationship between religion and politics at the time of the Prophet Muhammad. manifested itself in the society of Medina. Prophet Muhammad SAW. during his ten years in the city of hijrah he has emerged as a recipient of the holy message and a leader of the political community. In carrying out his role as a prophet, he is someone who cannot be denied because he has a mandate. Meanwhile, in carrying out his role as head of state, he conducts deliberations-according to God's orderswhich in these deliberations he often takes the opinions of others and leaves his own opinionAli Mahmudov, 2012).

History records that the city of the Prophet's migration. is a fertile oasis environment and inhabited by pagans from the main tribes of Aus and Khazraj, as well as Jews from the main tribes of Banu Nadzir, Bani Qoinuqo, Banu Quraizhah. This city was originally named Yathrib then changed by the prophet to Medina (Nurcholis Madjid, 1998: 51). Medina used by the Prophet SAW. To change the name of the city of his migration, we take it as a direct sign that the new place wants to create an orderly society as a society. So a Medina concept is a polite pattern of social life, which is enforced on the basis of obligations and general awareness to comply with applicable regulations or laws (Ali Mahmudov, 2012).

The political system of government formed by the Prophet Muhammad. is a Theo-democratic system pattern, on the one hand the social order must be based on laws where the law is based on revelations sent down by God in responding to every event at that time. On the other hand, the form of government and social order was formulated through a deliberation process carried out jointly with the tribes in Medina society. When contextualized with the current system of government, the structure of the government structure consists of the executive, judiciary and legislative. The executive where the head of government is held by the Prophet Muhammad, as well as in the constitutional and legal courts are all determined by the Prophet Muhammad. as a policy maker in addition to determining the form of community order concerning the plurality of citizens of Medina. In the realm of the legislature, every tribe in Medina has equal rights in expressing opinions in determining the social order of society such as in creating the constitution of the Medina Charter (Abu al-A'la Al-Maududi, 1988).

How the Prophet SAW. practice democracy in running the wheels of government? It has often been said that the Prophet SAW. will always be guided by the Qur'an in deciding something. However, if there are things that have not been 
regulated in the Qur'an, it is not uncommon for the Prophet to invite his friends to consult. Of course, if we relate it to the context of a modern state which is much more complex as it is today, the deliberation process that was carried out at the time of the Prophet SAW actually it is not substantially different from what is shown by the current political process, namely what we know as representative democracy, because we also understand that the Prophet SAW. in conducting deliberation does not involve all citizens who already have a "political franchise",Bernard Lewis, 2002, 123).

According to someexperts, such as Muhammad Khalid (1955), Muhammad Jalal al-Din Surur (1952), and Maulvi Muhammad Ali (1924), as well as Zainal Abidin Ahmad, Ahmad Sukarja (1956) and J. Suyuthi Pulungan (1996) in their respective books, they differ in formulating the basic principles of "democratic life" in the socio-political ideals of the Medina Charter, which consists of 47 articles. However, from the diversity of these formulations, briefly general points can be drawn that the basic principles that form the basis for a democratic state life for all times and places are:

1) The principle of the unity of the people, nation, community (ummah wahidah)

2) Collectivity and social solidarity

3) Protection and defense of the weak and oppressed

4) Social justice

5) Peace between each other and the environment

6) Equality before the law

7) Freedom of opinion, association, expression and religion

8) Upholding human rights

9) Nationalism

10) Social equality

11) Deliberation (Ngudi Astuti, 2012: 298).

Al-Qur'an and al-Hadits do not talk much about politics and government, but historical facts at the time of the Prophet SAW. and Khulafaurrasyidin also used some principles taken from the Qur'an. A. Maftuh Agebriel stated, as quoted by Ngudi Astuti, there are seven principles in the Qur'an that can be recommended regarding the life of the nation and state, namely: Deliberation, equality and brotherhood, justice, freedom, trust, peace, and tolerance (Ngudi Astuti, 2012: 294). Meanwhile, according to Islamic principles, the government that must be obeyed is as long as it does not rule against disobedience, then if there is a group that has the power to disobey the government, then it is considered a dissident/rebel (bughat). Because the occupation in Islam is understood as a mandate that has two sides of responsibility, vertical and horizontal.

\section{Conclusion}

The principles of human rights in the Medina Charter consist of; the principle of justice, the principle of equality, the principle of religious freedom, and the principle of piety, amar makruf and nahi munkar. The discussion of these four principles basically includes several other principles contained in the Medina Charter, including: the principle of unity and brotherhood, the principle of living as neighbors, neighbors, nation and state, the principle of defense (defense of the state) and the principle of deliberation and consensus, as well as the principle of implementing the law.

Implementation of human rights values in The Medina Charter in the Indonesian context, the author summarizes the study into three areas of religious, national and state life, namely: the field of religious harmony, the field of law and its relevance to the enforcement of the constitution and the field of socio-political life and the development of the political system. The author asserts that from these findings, the Medina Charter in addition to containing principles that aim to maintain human rights (huquq al-adam) for the people of Medina and their inter-relationships. He also established the principle that the Muslim community of Medina is responsible for actualizing Allah's rights (huquq Allah), namely His commands and abandoning His prohibitions both related to Him and with fellow human beings, this term is called taqwa.

The Medina Charter also contains ideas that have strong relevance to the developments and desires of the world community today, especially for Indonesia. The ideas in the Medina Constitution were also absorbed by the founding figures of the Indonesian nation, which can be seen in the Jakarta Charter which later gave birth to Pancasila. The contents of 
the Medina Charter and Pancasila have in common as a sentence of sawa' (meeting point) diversity or a noble agreement that is constructive, loves, and defends Indonesia, as well as the Medina Charter.

Basically, principles of human rights is the goal of Islamic shari'a or maqashid al-shari'a (the philosophy of Islamic law) which has been formulated by al-Ghazali and perfected by asSyatibi. These principles are summarized in aldlaruriyah al-khamsah or also called al-huquq al-insaniyah fi al-Islam (human rights in Islam). This concept consists of five basic principles that must be maintained and respected by every individual; Hifzhu al-Din (respect for religious freedom), Hifzhu al-Mal (respect for property), Hifzhu al-Nafs wa al-'Irdl (respect for life, right to life and individual honor), Hifzhu al-'Aql (respect for for freedom of thought), and Hifzhu al-Nasl (respect for keeping offspring).

\section{References}

\section{Book}

Ahmad, Abidin, Zainal. (2014). Piagam Madinah: Konstitusi Tertulis Pertama di Dunia, Jakarta: Pustaka Al kautsar, Cetakan II. (1956). Membentuk Negara Islam, Jakarta: Bulan Bintang.

Al-Wahidi. (1984). Asbab Nuzul Al-Qur'an t. tp.: Dar alQiblah li al-Saqafah al-Islamiyyah, Cetakan ke-2.

An-Naim, Ahmed, Abdullah. (2007). Islam dan Negara Sekuler: Menegoisasikan Masa Depan Syariah, Bandung: Mizan Pustaka.

Azizy, Qodri. (2004). Melawan Golbalisasi Reinterpretasi Ajaran Islam: Persiapan SDM dan Terciptanya Masyarakat Madani, Yogyakarta: Pustaka Pelajar.

(2000). Masyarakat Madani Antara Cita dan Fakta; Kajian Historis Normative, dalam Ismail SM dan Abdul Mukti (Editor) Pendidikan Islam Demokratisasi dan Masyarakat Madani, Yogyakarta: Pustaka pelajar, Cet. I.

Clack, George .(1998). Hak Asasi Manusia Sebuah Pengantar, (terjemahan Termaya), Jakarta: Pustaka Sinar Harapan.

Dahlan, Aziz, Abdul (et.al). (1996). Ensiklopedia Hukum Islam, jakarta: Ichtiar baru van Hoeve.

Dawud, Abu. (1952). Sunan Abu Dawud, Jilid II, Maktabah Mushthafaal, Bab al-Harabi, Mesir.

Donnely, Jack. (2003). Universal Human Right in Theory and Practice, Ithaca and London: Cornell University.

El-Hakim, Imammullah, Muhammady, Himas. (2015) Prinsip Konstitusionalisme Dalam Piagam Madinah Dan Relevansinya Bagi Konstitusi Indonesia, Fakultas Hukum Universitas Airlangga Surabaya.
Hasan, M. Iqbal. (2003). Pokok-pokok Materi Metodologi Penelitian dan Aplikasinya, Jakarta: Ghalia Indonesia.

Irianto, Sulistyowati dan Shidarta. (2009). Metode Penelitian Hukum: Konstelasi dan Refleksi, Jakarta: Yayasan Pustaka Obor Indonesia.

Ibn Hisyam, Abdul Malik, Abu Muhammad. (1329 H). AsSirah An-Nabawiyah Li Ibn Hisyam, Mesir: Matba'ah al-khairiyah, Cet. Pertama, Juz II.

Kamus Besar Bahasa Indonesia Depdikbud. (1988). Kamus Besar Bahasa Indonesia, Jakarta: Balai Pustaka.

K.M. Smith, Rhona (et.al). (2008). Hukum Hak Asasi Manusia, Yogyakarta: PUSHAM UII.

Misrawi, Zuhari. (2009). Madinah, Jakarta: Kompas.

Muhadjir, Noeng, , dkk. (2000). Metodologi Penelitian Kualitatif, Yogyakarta: Rave Sarasin.

Pulungan, J. Suyuthi. (1996). Prinsip-Prinsip Pemerintahan Dalam Piagam Madinah, Jakarta: Raja Grafindo Persada.

Putra, Dalizar. (1995). Hak Asasi Manusia menurut alQur'an, Jakarta: PT. Al-Husna Dzikra.

Shapiro, Ian. (2006). Evolusi Hak dalam Teori Liberal, Jakarta: Yayasan Obor Indonesia.

Sjadzali, Munawir. (1993). Islam dan Tata Negara: Ajaran, Sejarah, dan Pemikiran, Edisi V, Jakarta: UI-Press.

Soekanto, Soerjono \& Mamudji, Sri. (2001). Penelitian Hukum Normatif (Suatu Tinjauan Singkat), Jakarta: Rajawali Pers.

Suaedy, Ahmad (et.al). (2009). Islam, Konstitusi dan Hak Asasi Manusia: Problematika Kebebasan Beragama dan Berkeyakinan, Jakarta: The Wahid Institute.

Sukardja, Ahmad. (2014). Piagam Madinah \& UUD NRI 1945, Jakarta: Sinar Grafika, 2014.

Wignjosoebroto, Soetandyo. (2002). Hukum, Paradigma Metode dan Dinamika Masalahnya, Editor : Ifdhal Kasim et.al., Elsam dan Huma, Jakarta.

Yahya, Mukhtar dan Fatchurrahman. (1986). Dasar-dasar Pembinaan Hukum Islam: Fiqh Islami, Bandung: PT. Al-Ma'arif.

Zainab, Al-Khudhairi. (1995). Filsafat Sejarah Ibnu Khaldun, Bandung: Penerbit Pustaka, 1995.

\section{Article/Paper}

AM, Arief. (2015). Hak Asasi Manusia Dalam Perspektif AlQur'an.

Asmarani, Nur. (2015). Teori Hak Asasi Manusia (HAM), Jurnal Hukum dan Masyarakat, Volume 14, No. 1, Januari.

Bakar, Abu dan Hurmain. (2016). KERUKUNAN ANTARUMAT BERAGAMA; Telaah Atas Piagam Madinah dan Relevansinya Bagi Indonesia, UIN Sultan Syarif Kasim Riau, Jurnal TOLERANSI: Media Komunikasi umat Beragama, Vol. 8, No. 2, JuliDesember.

Lewis, Bernard. (2002). Islam Liberalisme Demokrasi: membangun sinergi warisan sejarah, doktrin dan konteks global, Jakarta: Paramadina.

Madjid, Nurcholis, (1998). Jurnal Paramadina, vol.1, no 1, juli-desember.

Marzuki. Kerukunan Antarumat Beragama Dlam Wacana Masyarakat Madani Analisis Piagam Madinah \& Relevansinya Bagi Indonesia. Lihat di: 
http://www.artikelmarzuki kerukunan antaruma t beragama dlam wacana masyarakat madani an alisis_Piagam_madinah_\&relevansinya_bagi_indon esia.com

Rangkuti, Afifa, SH., M.Hum. (2017). Konsep Keadilan Dalam Perspektif Islam, Jurnal Pendidikan Islam, Vol.VI, No.1, Januari-Juni.

Priyono, Eko. Prinsip-Prinsip negara Hukum dalam Piagam Madinah dan Konstitusi Indonesia; Suatu Analitis Deskriptif Komparatif, 2006. Lihat di: http://student-

research.umm.ac.id/index.php/twinning_program /article/view/6439

\section{Legislation}

UUD 1945

Undang-Undang No. 39 Tahun 1999 tentang Hak Asasi Manusia.
KUHP, Pasal 87, Pasal 104, Pasal 106, Pasal 107, Pasal 108, Pasal 110 dan Pasal 140 tentang Makar.

Tap MPR No. XVII/MPR/1998 tentang HAM

\section{Internet}

Elviandri, Hak Asasi Manusia Dalam Perspektif Islam; Kajian Konsep dan Historis, dalam http://www.Hukumonline.com, diakes pada 11 Juni 2021 pukul 22.30 WIB.

Fikri, M. Ainul, Prinsip Persamaan (Al-Musawah) Dalam Islam, 2015. Bisa diakses melalui: http://fikriainul.blogspot.co.id/2015/01/prinsip-persamaanal-musawah-dalam-islam.html

KH. Zainuddin Mz, Sholeh Pribadi Dan Sholeh Sosial, Ceramah Agama, bisa diakses melalui: https://www.youtube.com/watch?v=kd5j3t18wR $\underline{4}$ 